Sādhanā Vol. 38, Part 3, June 2013, pp. 477-490. (c) Indian Academy of Sciences

\title{
Analysis of the quality renovated continuous steel casting roller
}

\author{
J VIŇÁŠ́， J BREZINOVÁ and A GUZANOVÁ
}

Department of Technology and Materials, Faculty of Mechanical Engineering, Technical University of Košice, Mäsiarska 74, 04001 Košice, Slovakia e-mail: jan.vinas@tuke.sk

MS received 3 February 2012; revised 10 September 2012; accepted 3 October 2012

\begin{abstract}
This paper presents the possibility of restoration of worn contact surfaces of rollers for continuous casting of steel. Permanent effort of steel producers to extend the lifespan of these components requires the implementation of new filler materials or modifying technological renovation processes to reduce the economic costs. This matter seems to be very important for the world leaders in steel production, e.g., ArcelorMittal, Tata Steel, but also for smaller concerns such as Magnitogorsk Iron and Steel Works, Salzgitter, etc. Renovation of continuous steel casting rollers, made of X12Cr13 EN 10088-1-97, was realised using submerged arc surfacing technology. Worn surface of roller was machined and surfaced using one interlayer and two cover layers. The quality of deposited layers was verified using non-destructive and destructive tests. The influence of filler material on the tribological properties of contact surfaces of deposited layers was analysed by abrasive wear test. Studies were made in the influence of surfacing parameters on cladding metal mixing (mixed) with base metal and also influence of heat introduced by welding using metallographic analysis. The experiments confirmed very good wear resistance of the applied filler metal due to dispersion strengthening caused by finely dispersed carbides and nitrides in the weld coating. The measures to be taken into account in renovation of rollers using hard surfacing, as well as the development of research in this area were also given. The experiments have confirmed that parameters used are suitable for studying filler materials.
\end{abstract}

Keywords. Renovation; wear; abrasion; microstructure; layer; continuous casting.

\section{Introduction}

For reliable operation of continuous slab casters the lifespan of rolls which provide movement of slabs in the line is very important. During steel production, rolls are loaded with the combination of wear and thermal fatigue caused by thermal shocks while moving slabs in the temperature range from $1280^{\circ} \mathrm{C}$ to $850^{\circ} \mathrm{C}$, and also with high-temperature corrosion (Bhattacharya \&

*For correspondence 
Sambasivam 2009; Mazumdar \& Ray 2001). The combination of these stresses causes rapid wear on the surface of new rolls. Currently, the renovation of continuous steel casting rolls is realized by submerged arc surfacing technology. From the tribological point of view rolls are loaded by adhesive-abrasive wear. In contact between roller and slab adhesive wear together with micro-welds occur. Low-cycle fatigue causes depletion of plastic deformation and fatigue failure of the material layers with gradual separation. The abrasives (remains of casting powder, corrosive products) present on the slab cause wear of the groove roll surface. Continuous casting rolls operate in an extremely aggressive environment, which causes a reaction of free hydrogen ions with slag of high fluorine content. Corrosive pitting appears on the surface of the roll which acts as a centre of fatigue cracks origin. Corrosion under stress proceeds, according to Blaškovitš \& Čomaj (2006) and Blaškovitš et al (2001) in concurrence of chlorine from the cooling water in the high-temperature loading primarily in the areas of fatigue cracks. Stress intensity is determined by thermal gradient and thermal expansion of steel in the surface layers (Kasala et al 2009, 2010). A practical criterion for exclusion from the operation of the roll is the development of the main crack in excess of weld overlay thickness, which could be either $1 \mathrm{~mm}$ diameter wear on the cylinder, or corrosive-fatigue crack of $4 \mathrm{~mm}$ depth, which initiates fracture of the cylinder (Čomaj \& Šef̌́ík 1999).

Lifespan of rollers, depending on their incorporation in the continuous casting line is given in the range of $150-1000.10^{3} \mathrm{t}$ of steel (Slavkovský 1987).

\subsection{Analysis of the present state in the process of renovating rolls}

Continuous casting rolls are made of creep resistant low alloy steel $\mathrm{C}-\mathrm{Cr}-\mathrm{Ni}$, type $\mathrm{X} 12 \mathrm{Cr} 13$ EN 10088-1-97 or, type X20Cr13 EN 10088-1-97 which has insufficient resistance to their real operational stress. For the renovation of the roll surface currently chromium claddings with chromium content exceeding passivation threshold of $12 \%$ and carbon content up to $0.18 \%$ are used. The first generation of cladding systems contains carbon in the range of 0.15 to $0.18 \%$, chromium content up to $13 \%$ with martensite structure supplied as tapes or flux cored wires for submerged arc surfacing. To reduce the rate of corrosive-fatigue cracks formation there was the second generation of surfacing materials with lower carbon content ranging from 0.03 to $0.07 \%$ with 13-17\% chromium content with martensitic-ferritic structure (ferrite content up to $10 \%$ ). The limiting factor in using these materials, however, became wear resistance of the system. Adding nitrogen to chromium claddings to compensate for the deficit carbon, the cladding systems of the third generation appeared using open arc surfacing technology. Formation of $\mathrm{CrN}$, $\mathrm{Cr}_{2} \mathrm{~N}$ resulted in increasing hardness already at low carbon content. Nitrides in the cladding metal lock dislocations, grain growth and the formation of $\mathrm{Cr}_{23} \mathrm{C}_{6}$ carbides, which resulted in reducing the resistance to thermal fatigue, creep and aging of the cladding system. Next, the decrease in Ms temperature results in the formation of fine-grained martensite during solidification in the cladding and also in HAZ (Heat Affected Zone during welding). From the range of cladding materials of the third generation materials marked UP5-GF-45-C DIN 8555 are used. These materials create the conditions for nitride $\mathrm{Cr}_{2} \mathrm{~N}$ formation and reduce Ms temperature to around $200^{\circ} \mathrm{C}$ (Čomaj \& Šefčík 1999).

\section{Materials and methods}

Experimental works were aimed on the evaluation of rolls repaired by submerged arc welding (SAW). Renovating worn roll comes from curved sector, (figure 1) of continual steel casting 


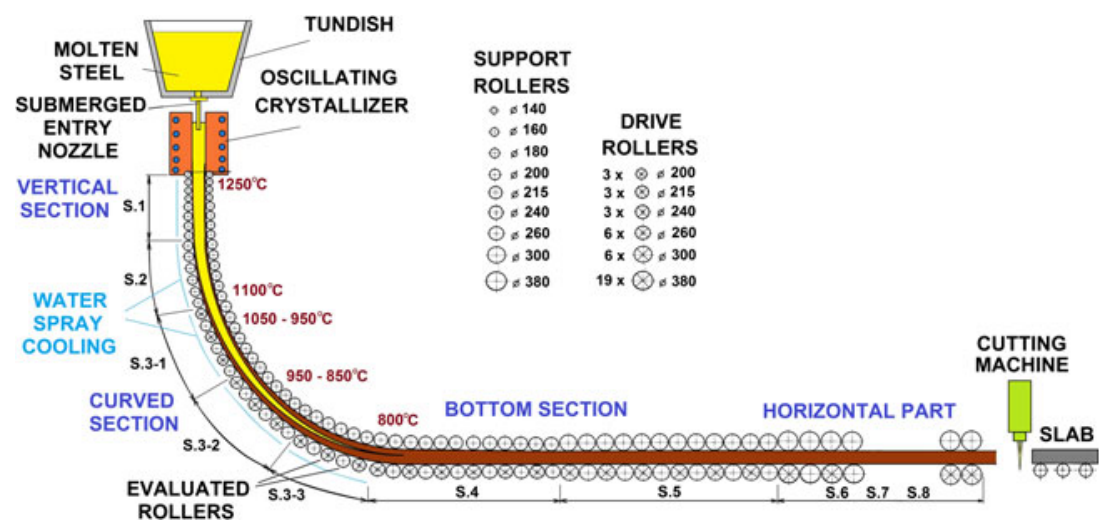

Figure 1. Schematic of continuous casting of steel.

line made of material X12Cr13 EN 10088-1-97 by forging. Chemical composition and mechanical properties of roll steel are shown in tables 1 and 2. Bending radius of line curved sector is $10000 \mathrm{~mm}$. Mentioned line is able to produce slabs with section of $190-250 \mathrm{~mm} \times 960$ $1900 \mathrm{~mm}$. Metallurgical length of melt solidification in whole slab section is $28731 \mathrm{~mm}$. The casting line is designed for casting rate varying from 0.2 to $2.5 \mathrm{~m} \cdot \mathrm{min}^{-1}$ (Slavkovský 1987).

In top vertical section rolls with diameter from 150 to $200 \mathrm{~mm}$, in curved and bottom section from 200 to $380 \mathrm{~mm}$ are used. Diameter of repaired roll was $240 \mathrm{~mm}$. Figure 2 shows worn out of continuous steel casting rollers, designed to assess the extent of wear. Figure 3 shows rollers surfaces after turning.

\subsection{Process of rolls repairing}

When there is a presence of some cracks on rolls, or change of geometry or dimensions due to wear in operation, the roll has to be disabled for repairing (Viňáš \& Kaščák 2008a, b; Viňáš 2003). Whether the roll is repairable or not is decided by observing the functional roll surface through visual and ultrasonic checks. According to defect, the repairing possibility is considered. Returned roll dedicated for repairing has to be degreased. Next roll is preheated on $280^{\circ} \mathrm{C}$ in electric furnace. There is a specified number of claddings (independence on thickness of

Table 1. Chemical composition of X12Cr13 EN 10088-1-97 (in wt.\%).

\begin{tabular}{lccccccr}
\hline $\mathrm{C}$ & $\mathrm{Mn}$ & $\mathrm{Si}$ & $\mathrm{Cr}$ & $\mathrm{Ni}$ & $\mathrm{P}$ & $\mathrm{S}$ & $\mathrm{Fe}$ \\
\hline 0.19 & 1.34 & 0.85 & 12.3 & 0.6 & 0.02 & 0.015 & bal.
\end{tabular}

Table 2. Mechanical properties of X12Cr13 EN 10088-1-97.

\begin{tabular}{lcccc}
\hline $\begin{array}{l}\text { Yield strength } \\
{[\mathrm{MPa}]}\end{array}$ & $\begin{array}{c}\text { Tensile strength } \\
{[\mathrm{MPa}]}\end{array}$ & $\begin{array}{c}\text { Elongation } \\
{[\%]}\end{array}$ & $\begin{array}{c}\text { Impact energy } \\
{\left[{\left.\mathrm{J} . \mathrm{cm}^{-2}\right]}^{-2}\right.}\end{array}$ & $\begin{array}{c}\text { Hardness } \\
\text { HV 30 }\end{array}$ \\
\hline 470 & 820 & 15 & 28 & 224 \\
\hline
\end{tabular}




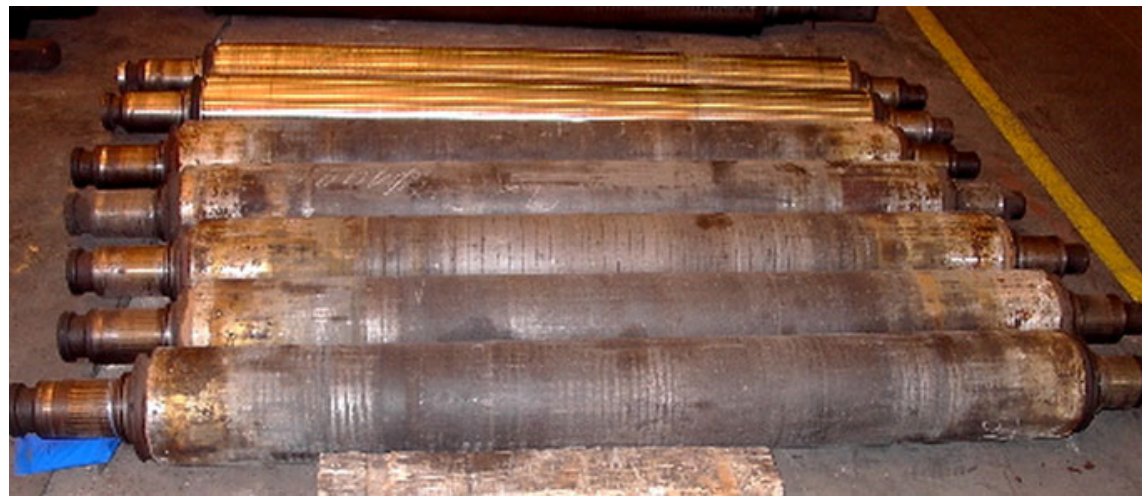

Figure 2. Worn out rollers of steel continuous casting (Šúň 2007).

removed worn layer) applied on preheated roll. During surfacing, the temperature of preheating is maintained with the help of the flame heating. After surfacing, the stress relief annealing follows in duration of a few hours and consequently slow cooling in isothermal wrap. After thermal treatment, turning, boring and roll surface grinding follows to the specified dimensions. After cutting operations, the roll surface is checked by ultrasound to assess its suitability for the casting operation.

Cladding was realised by SAW technology with the help of the welding machine, which enables to vary parameters of roll rotation during cladding. Welding position used according to STN EN ISO 6947- PA. This position is most suitable for repairing of rotary surfaces and by using a flux it is usable without other technology modifications of welding machine, (figure 4).

There were three cladding layers deposited on the roll surface. The first layer deposited on the base material was the interlayer of thickness approximately $2.5 \mathrm{~mm}$, made of welding wire by UP-5-200-C DIN 8555 in combination with aluminous - basic flux S F AB 165 AC H5 EN 760. Current polarity was DC + . Chemical composition of welding wire and flux used in the study is shown in tables 3 and 4. Cladding hardness provided by welding wire producer is $210 \mathrm{HV} 30$.

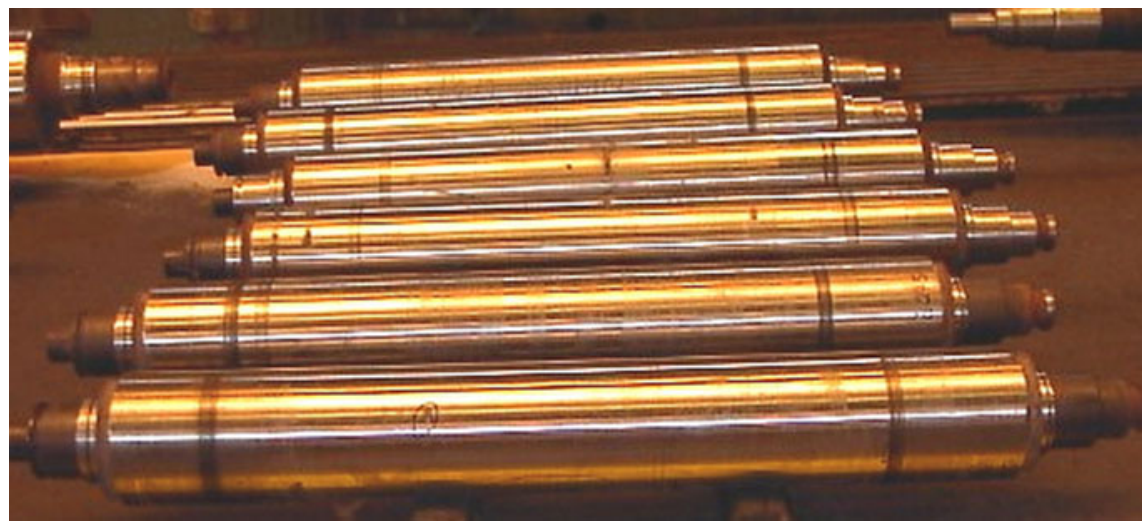

Figure 3. Turned rollers (Šúň 2007). 


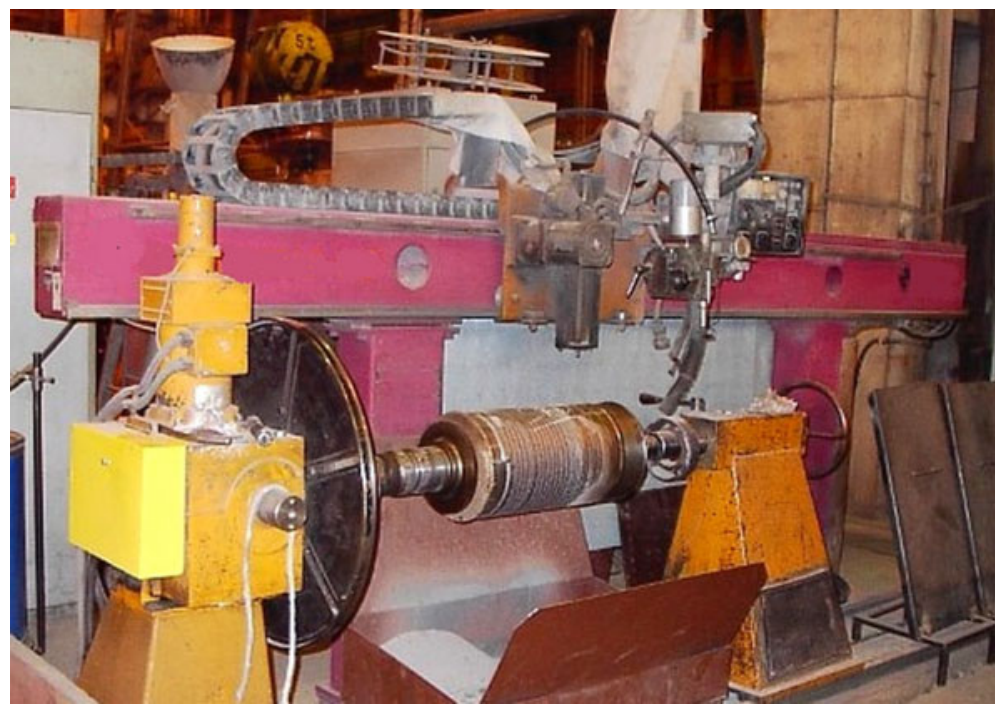

Figure 4. Welding machine designed for renovation continuous steel casting rollers and rollers of rollingmill train (Š́ún 2007).

Flux was dried for $1 \mathrm{~h}$ at $300^{\circ} \mathrm{C}$ before cladding. Properties of flux used are as follows: basicity index 1.3, flux granularity $0.2-2.0$, density $1.2 \mathrm{~kg}_{\mathrm{dm}} \mathrm{dm}^{-3}$, suitable for AC and also DC welding current supply, hydrogen content $\leq 5 \mathrm{HDM}$.

Next, there were two cover layers deposited using welding wire UP-5-45-C DIN 8555 and the same aluminous - basic flux as in previous S F AB 165 AC H5 EN 760 by SAW technology on interlayer. Current polarity was DC + . Chemical composition of welding wire used for cover layers is given in table 5 . Cover cladding hardness provided by welding wire producer is 450 HV 30. Thickness of cover layer was approximately $6 \mathrm{~mm}$.

Technological parameters are given in table 6 . Roll preheating temperature is $260^{\circ} \mathrm{C}-270^{\circ} \mathrm{C}$. During welding process the interpass temperature was maintained with the help of gas-burners at $200^{\circ} \mathrm{C}-380^{\circ} \mathrm{C}$.

After cladding, the roll was heated to $500^{\circ} \mathrm{C}\left( \pm 10^{\circ} \mathrm{C}\right)$, soaked for $4-5 \mathrm{~h}$ and finally cooled slowly (cooling rate $40^{\circ} \mathrm{C}$ per $\mathrm{h}$ ) to the temperature of $210^{\circ} \mathrm{C}$ in isothermal wrap for stress relieving treatment. When the roll temperature was $210^{\circ} \mathrm{C}$, cooling was continued in air. According

Table 3. Chemical composition of weld wire UP-5-200-C DIN 8555 (wt.\% less than) (VUZ-PI 2011a).

\begin{tabular}{lcccccccc}
\hline $\mathrm{C}$ & $\mathrm{Mn}$ & $\mathrm{Si}$ & $\mathrm{Cr}$ & $\mathrm{Mo}$ & $\mathrm{V}$ & $\mathrm{W}$ & $\mathrm{Ni}$ & $\mathrm{Fe}$ \\
\hline 0.06 & 0.9 & 0.5 & 17.5 & - & - & - & - & bal. \\
\hline
\end{tabular}

Table 4. Slag analysis of flux S F AB 165 AC H5 EN 760 (in wt.\%) (VUZ-PI 2011b).

\begin{tabular}{lccccccccccc}
\hline $\mathrm{SiO}_{2}$ & $\mathrm{MnO}$ & $\mathrm{Fe}_{2} \mathrm{O}_{3}$ & $\mathrm{Al}_{2} \mathrm{O}_{3}$ & $\mathrm{CaO}$ & $\mathrm{MgO}$ & $\mathrm{CaF}_{2}$ & $\mathrm{Na}_{2} \mathrm{O}$ & $\mathrm{K}_{2} \mathrm{O}$ & $\mathrm{BaF}_{2}$ & $\mathrm{P}$ & $\mathrm{S}$ \\
\hline 13 & 0.6 & 0.8 & 42 & 10 & 0.8 & 29 & 0.3 & 2.5 & 1 & 0.04 & 0.04 \\
\hline
\end{tabular}


Table 5. Chemical composition of weld wire UP-5-GF-45-C DIN 8555 (wt.\% less than) (VUZ-PI 2011a).

\begin{tabular}{ccccccccccc}
\hline $\mathrm{C}$ & $\mathrm{Mn}$ & $\mathrm{Si}$ & $\mathrm{Cr}$ & $\mathrm{Mo}$ & $\mathrm{V}$ & $\mathrm{W}$ & $\mathrm{Ni}$ & $\mathrm{Nb}$ & $\mathrm{N}_{2}$ & $\mathrm{Fe}$ \\
\hline 0.1 & 0.9 & 0.5 & 13.5 & 1.2 & 0.3 & - & 2.3 & 0.2 & 0.12 & bal.
\end{tabular}

Table 6. Parameters of roll cladding.

\begin{tabular}{lccccccc}
\hline Layer & $\begin{array}{c}\text { Cladding } \\
\text { wire }\end{array}$ & $\begin{array}{c}\text { Size of } \\
\text { filler material } \\
{[\mathrm{mm}]}\end{array}$ & $\begin{array}{c}\text { Welding } \\
\text { current } \\
{[\mathrm{A}]}\end{array}$ & $\begin{array}{c}\text { Welding } \\
\text { voltage } \\
{[\mathrm{A}]}\end{array}$ & $\begin{array}{c}\text { Speed } \\
\text { oscillation } \\
{[\mathrm{cm} / \mathrm{min}]}\end{array}$ & $\begin{array}{c}\text { Speed of } \\
\text { welding } \\
{[\mathrm{cm} / \mathrm{min}]}\end{array}$ & $\begin{array}{c}\text { Weldboat } \\
\text { width } \\
{[\mathrm{mm}]}\end{array}$ \\
\hline 1 & UP-5-200-CZ & $\varnothing 2.8$ & $280-350$ & $27-35$ & 45 & 29 & 34 \\
2.3 & UP-5-45-C & $\varnothing 3.2$ & $300-370$ & $28-29$ & 45 & 31 & 35 \\
\hline
\end{tabular}

to STN EN 25 817, the required quality rank was 'B'. Cladding quality was evaluated by visual test according to STN EN 970 together with the capillary test according to STN EN 1289 and ultrasonic detection according to STN EN 1712.

Before repairing process itself it is necessary to take into account all characteristics of repaired material of roller, which eventually would be able to negatively influence the cladding quality during or after hardfacing process (Coe 1973; Viňáš \& Kaščák 2008a, b; Hrivňák 1972). Choice of incorrect technological arrangements can lead to considerable economic loss. Therefore, it is necessary to define tendency of repaired materials to cold, hot, underclad, annealing and lamellar cracks origin before repairing process.

\section{Results and discussion}

\subsection{Hardness measurement}

Vickers hardness measurement was done according to STN EN 1043-1 in defined spacing on roll cross-section with $30 \mathrm{kN}$ load used. Results of hardness measurement are shown in figure 5 .

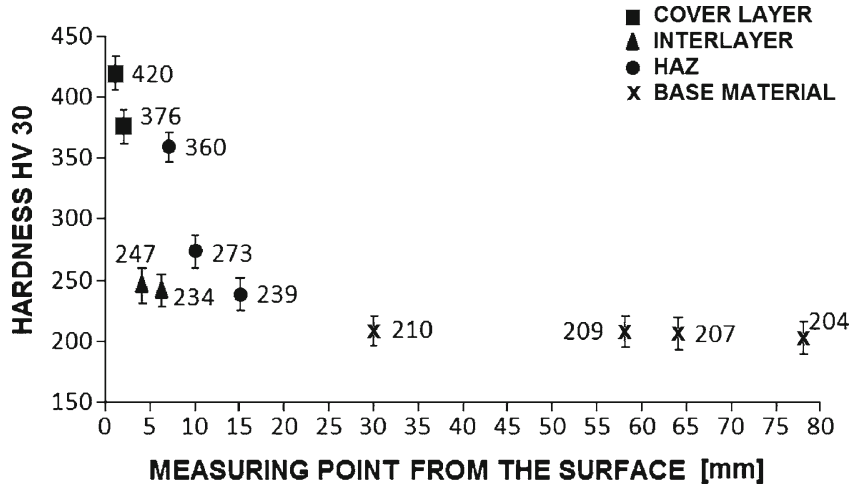

Figure 5. The hardness of claddings and base material. 
Maximum hardness value of HAZ, which is often critical region at repaired rolls can be expressed mathematically (Nakamura et al 1969):

$$
\mathrm{HV} \max =90+1050 \mathrm{C}+47 \mathrm{Si}+75 \mathrm{Mn}+30 \mathrm{Ni}+31 \mathrm{Cr}
$$

where C, Si, Mn, Ni and Cr [wt.\%].

Maximum hardness value of HAZ calculated for material X12Cr13 EN 10088-1-97 according to the Eq. (1) is HVmax $=827.72$, what is consistent with hardness value calculated using ProWeld 5.0 software from ThyssenKrupp Stahl. Microhardness of HAZ is significantly lower due to heat treatment after surfacing - long term annealing. The hardness of the under-weld material layers is also affected by the heat introduced during surfacing of cover layers, simultaneously reduction in hardness occurs due to annealing of under-weld material layers.

Maximum hardness value $420 \mathrm{HV} 30$ was found in cover layer, $1 \mathrm{~mm}$ from the surface. The lowest hardness values (from $204 \mathrm{HV} 30$ to $210 \mathrm{HV} 30$ ) were found in base material. Interlayer hardness is $234 \mathrm{HV} 30$ to $247 \mathrm{HV} 30$ which is higher than declared by the producer for the welding wire UP-5-200-CZ DIN 8555. Higher value of the hardness may be due to the mixing of cladding metal with cover layer metal.

\subsection{Metallographic analysis of roll}

Metallographic analysis was done according to STN EN 1321 on cross sections of particular cladding layers. Structure evaluation as well as photo documentation was carried out by the light microscopy and electron-scanning microscope. Chemical analysis of particular cladding layers and their transitional phases were carried out by the energy disperse spectrometer JEOL JSM-35 $\mathrm{CF}$ and LECO analyser. Considering $\mathrm{Cr}$ content in investigated materials, the etching solution with following composition was used for microstructure visualization: $0.3 \mathrm{ml}$ methanol, $0.3 \mathrm{ml}$ $\mathrm{HNO}_{3}, 0.3 \mathrm{ml} \mathrm{HCl}, 0.2 \mathrm{ml} \mathrm{C}_{6} \mathrm{H}_{3} \mathrm{~N}_{3} \mathrm{O}_{7}, 0.1 \mathrm{ml} \mathrm{C}_{3} \mathrm{H}_{8} \mathrm{O}_{3}$ ), etching time: 15 s. Figure 6 shows microstructure of roll base material X12Cr13 EN 10088-1-97- fine-grained martensite-ferrite.

Figure 7 shows the influence of heat introduced by welding on martensite-ferrite microstructure.

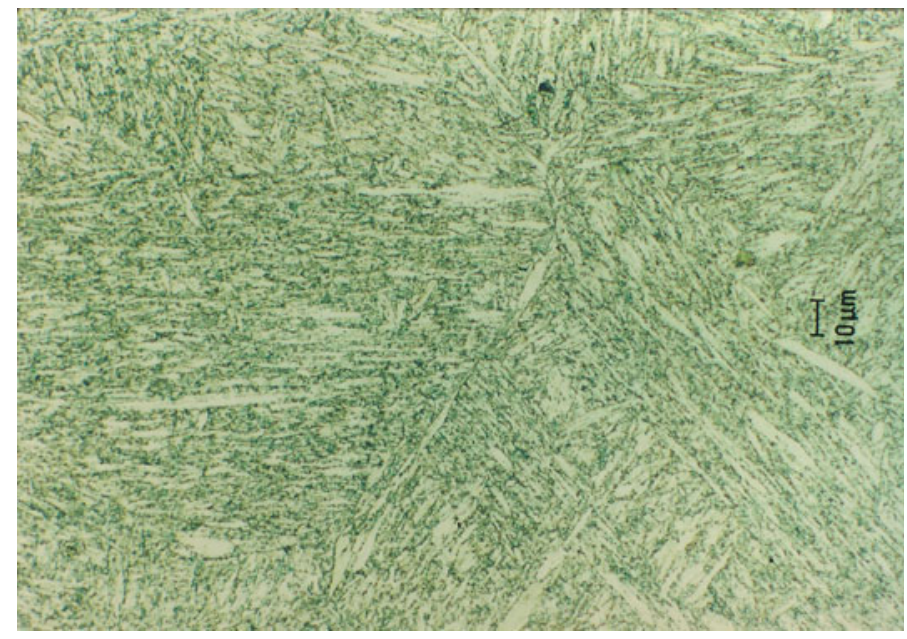

Figure 6. Martensite-ferrite structure of the base material. 


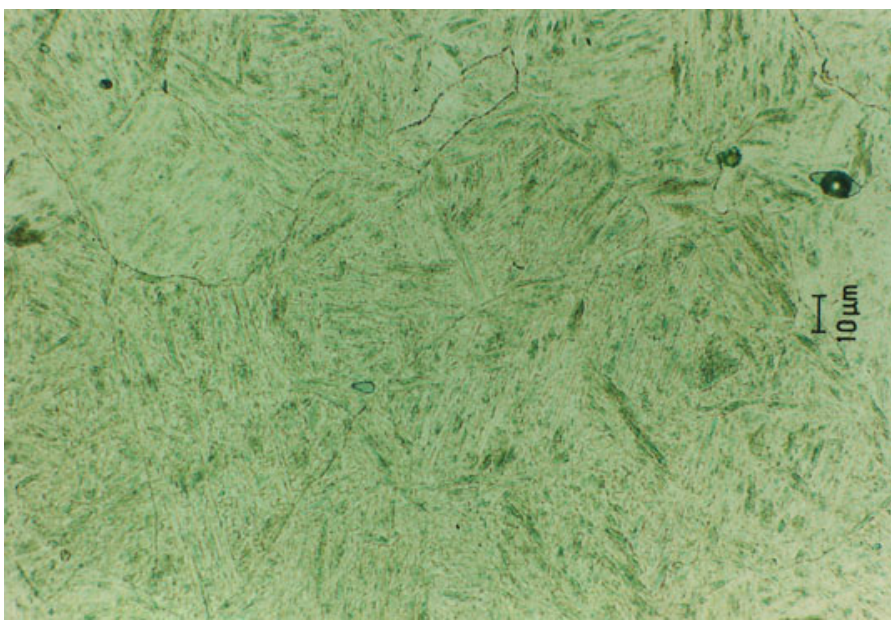

Figure 7. Microstructure of HAZ (martensite-ferrite).

The change of grain size and highlighting of grain boundaries are caused due to heat. The increased occurrence of inclusions and precipitates on grain boundaries was observed. Transition from the base material to HAZ is continuous. This region can be designated as critical. Choice of welding heat input requires increased attention particularly in martensitic structures of higher carbon contents. Heating promotes the formation of $\mathrm{MC}$ and $\mathrm{M}_{7} \mathrm{C}_{3}$ carbides which eventually segregate at the the grain boundaries. New rolls made out of X12Cr13 EN 10088-1-97 put into operation are expected to have high wear resistance, which is related with requirements on hardness of operating surfaces. This requirement can be met by surface hardening thanks to $\mathrm{Cr}$ carbides in martensitic matrix (Gooch 1977). But at repairing by cladding technology, the heat introduced by welding causes the growth and coarsening of $\mathrm{Cr}$ carbides. In operation, these carbides can initiate failure of functional roll surfaces. Thermal regime should be chosen so as to prevent the growth and coarsening of the martensite grains, which can cause lamellar cracks in

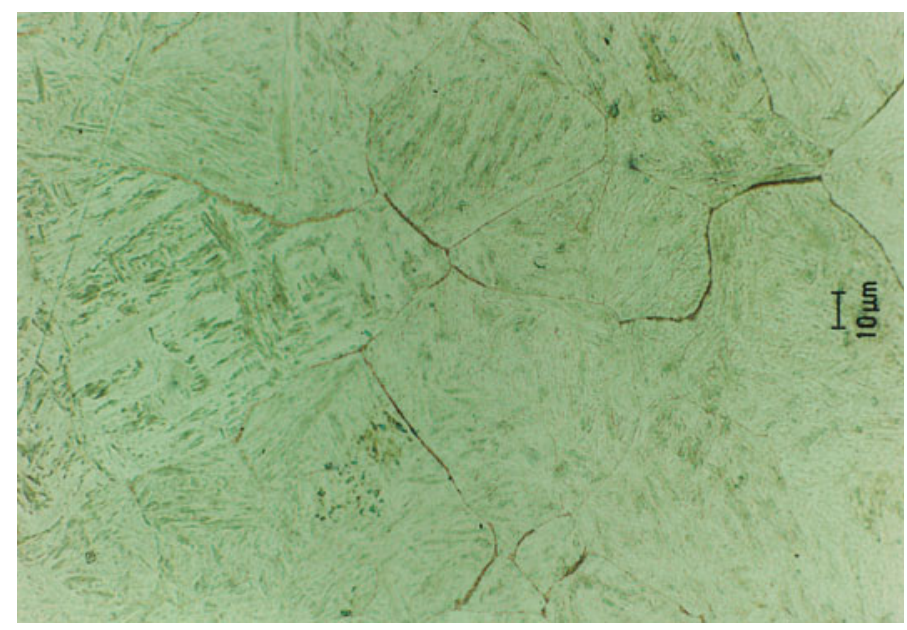

Figure 8. Microstructure of transitional the HAZ and interlayer. 


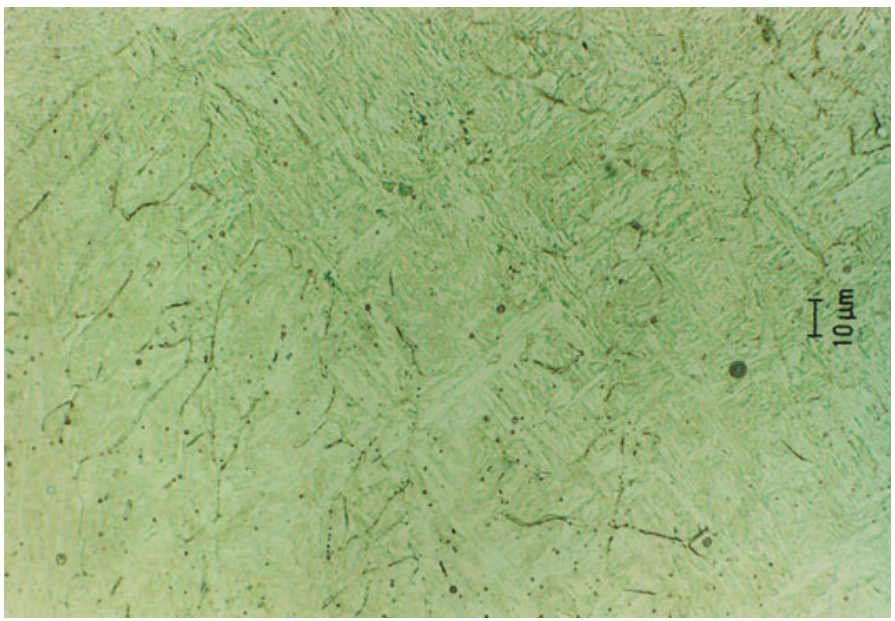

Figure 9. Microstructure of the interlayer (martensite-ferrite).

under-cladding areas. In cladding processes the formation of chromium carbides in the undercladding areas are favourable at the $\mathrm{C}$ and $\mathrm{Cr}$ content without $\mathrm{Ti}, \mathrm{Nb}$ and $\mathrm{N}$ in the base material. These fine-grained $\mathrm{Cr}$ carbides are dispersed at the grain boundaries (Viňáš \& Kaščák 2008a, b) which may cause roll failure. Thus, efforts must be made to avoid carbide formation in cladding processes.

Mixing of cladding and base metal took place on relatively narrow section, see figure 8 . Interlayer has a structure with characteristic epitaxial grain growth. Structure of interlayer, figure 9, made by welding wire UP-5-200-C DIN 8555 is martensite-ferrite, also called semi-ferritic structure. Fine precipitates were observed in the interlayer structure and character of diffraction spectrum of these carbides was $\mathrm{MC}, \mathrm{M}_{7} \mathrm{C}_{3}$ and $\mathrm{Cr}_{23} \mathrm{C}_{6}$. Structure of cover layer, figure 10, is martensite-ferrite. Thickness of cover layers after cutting operations to required dimension ranges from 3.0 to $3.5 \mathrm{~mm}$. The presence of $\mathrm{MC}, \mathrm{M}_{7} \mathrm{C}_{3}$ carbides was observed in cover layer,

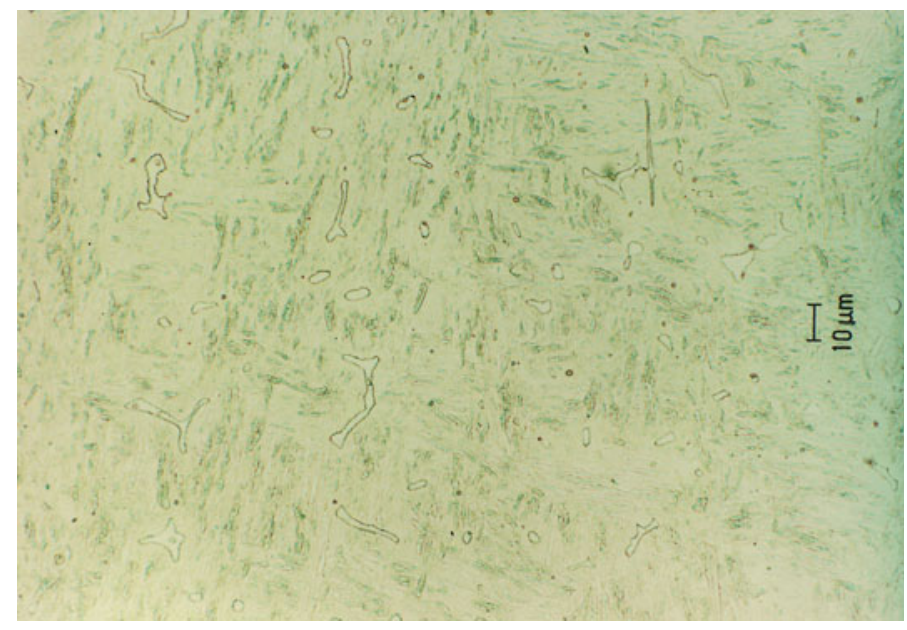

Figure 10. Microstructure of the cover layer with typical solidification grain. 
but in significantly lower volume; and EDX analysis proved the occurrence of $\mathrm{CrN}$ and $\mathrm{Cr}_{2} \mathrm{~N}$ nitrides as well.

The presence of inclusions of predominantly silicate-type was observed in cladding layers, which is in line with the previous work (Hrivňák 1972).

\subsection{Chemical analysis of repaired roll}

In addition to microstructures, mixing of particular cladding layers was also evaluated on crosssections by line EDX analysis. Length of evaluated section was $1 \mathrm{~mm}$. Average values of chemical composition of repaired roll depending on the distance of the working surface are shown in table 7.

EDX analysis proved chemical composition corresponding to welding wire declared by the manufacturer. Acceptable variations of chemical composition of cladding layers are in line with knowledge of the fluxes ionic theory at submerged arc welding. The change (reduction) of particular elements content ( $\mathrm{Mn}, \mathrm{Si}$ and $\mathrm{Cr}$ ) occurs in consequence of metallurgical processes at interactions between flux and welding wire during transfer of molten metal in electric arc. The example of this action is behaviour of $\mathrm{Si}$ in its transition from slag into the cladding metal at welding with wire containing $\mathrm{Cr}$.

Formation of the complex anion $\mathrm{SiO}_{4}^{4-}$ occurs at dissociation of the slag system at temperature over $1800^{\circ} \mathrm{C}$ by transition from the slag into filler metal only if the two following conditions are met:

if $\mathrm{nO}_{\mathrm{CH}}^{2-}$ has minus sign and if flux contains $\mathrm{SiO}_{2}$ (Zeke \& Jánošiová 1975; Zeke \& Mikula 1973). The transition mechanism of Si from the slag into the filler metal is defined by:

$$
2 \mathrm{SiO}_{2 \text { slag }} \rightarrow \mathrm{SiO}_{4 \text { slag }}^{4-}+\mathrm{Si}_{\text {slag }}^{4+}
$$

and

$$
\mathrm{Si}_{\text {slag }}^{4+}+2 \mathrm{Me}_{\text {metal }}=\mathrm{Si}_{\text {metal }}+2 \mathrm{Me}_{\text {slag }}^{2+} \text {. }
$$

The potential possibility of Si transition from the slag to the filler metal is given by the presence of $\mathrm{SiO}^{4+}$ cation in the slag. The quantity of mentioned cations is proportional to the product $\mathrm{nO}_{\mathrm{CH}}^{2-} \cdot \mathrm{NSiO}_{2}$ (Zeke \& Jánošiová 1975). References for four metallurgical flux characteristics are as follows.

$-n \mathrm{O}_{\mathrm{CH}}^{2-}-$ main metallurgical flux characteristic which expresses flux basicity/acidity in terms of ion theory of the slag systems:

$$
n O_{C H}^{2-}=\sum m \mathrm{R}_{2} \mathrm{O}+\sum m \mathrm{RO}-\left(2 m \mathrm{SiO}_{2}+m \mathrm{Al}_{2} \mathrm{O}_{3}+m \mathrm{TiO}_{2}\right)
$$

Table 7. Chemical composition of analysed roller (in wt.\%).

\begin{tabular}{lcccccccccc}
\hline $\begin{array}{l}\text { Distance of the } \\
\text { working roll surface }\end{array}$ & $\mathrm{C}$ & $\mathrm{Mn}$ & $\mathrm{Si}$ & $\mathrm{Cr}$ & $\mathrm{S}$ & $\mathrm{P}$ & $\mathrm{Mo}$ & $\mathrm{Ni}$ & $\mathrm{N}_{2}$ & $\mathrm{Nb}$ \\
\hline less than 1 mm & 0.074 & 0.789 & 0.511 & 12.874 & 0.012 & 0.014 & 0.651 & 3.141 & 0.134 & 0.147 \\
3-4 mm & 0.080 & 0.736 & 0.554 & 15.397 & 0.012 & 0.015 & 0.441 & 0.141 & 0.076 & 0.061 \\
$5-6 \mathrm{~mm}$ & 0.086 & 0.711 & 0.747 & 13.371 & 0.012 & 0.017 & 0.011 & 0.032 & 0.002 & 0.001 \\
$8-9 \mathrm{~mm}$ & 0.183 & 1.271 & 0.721 & 12.248 & 0.015 & 0.017 & 0.001 & 0.558 & 0.001 & 0.001 \\
$11-12 \mathrm{~mm}$ & 0.191 & 1.304 & 0.794 & 12.114 & 0.015 & 0.017 & 0.001 & 0.543 & 0.001 & 0.001 \\
\hline
\end{tabular}


Table 8. Main metallurgical characteristics of flux.

\begin{tabular}{cccc}
\hline $\mathrm{nO}_{\mathrm{CH}-}^{2-}$ & $\mathrm{KIR}_{\mathrm{Si}}$ & $\mathrm{KIR}_{\mathrm{Mn}}$ & $\mathrm{KIO}_{\mathrm{Cr}}$ \\
\hline-0.39 & -0.03 & 0.11 & 0.3 \\
\hline
\end{tabular}

where $m$ is mole number, $\mathrm{RO}$ - oxides of bivalent element, $\mathrm{R}_{2} \mathrm{O}$ - oxides of univalent element.

The silicon reduction intensity factor can be calculated according to:

$$
K I R_{\mathrm{Si}}=n \mathrm{O}_{\mathrm{CH}}^{2} \cdot N \mathrm{SiO}_{2} \cdot(1-\sqrt[3]{N \mathrm{MnO}}),
$$

where $N$ is the mole fraction.

The manganese reduction intensity factor can be calculated according to:

$$
K I R_{\mathrm{Mn}}=\sqrt{N \mathrm{MnO}} \cdot\left(1-\sqrt{K I R_{\mathrm{Si}}}\right),
$$

- $K I O_{\mathrm{Cr}}$ - coefficient of chromium oxidation which expresses the degree of oxidative flux character in relation to chromium. It enables to predict the chromium content in the filler metal at weld using chromium or chromium-nickel welding wires according:

$$
K I O_{\mathrm{Cr}}=\sqrt{\left|K I R_{\mathrm{Si}}\right|}+K I R_{\mathrm{Mn}} .
$$

Results of calculation for main metallurgical characteristics of flux according to Eqs. 4-7 are listed in table 8 .

\subsection{Abrasive wear of roller's functional surface}

Abrasive wear of repaired rolls was compared with the reference material of new roll with $4 \mathrm{~mm}$ thick surface hardened layer. Abrasive wear test, based on weight analysis, was performed on a laboratory device APGi, VEB Leipzig. The test device consists of a cylinder with a diameter of $150 \mathrm{~mm}$ with fixed abrasive coated paper. Test samples made out from evaluated materials have cylindrical shape with a diameter of $6 \mathrm{~mm}$ and height of $15 \mathrm{~mm}$. Contact force between the sample and abrasive paper was $10 \mathrm{~N}$. Grinding path travelled by the sample on the grinding cylinder is $40 \mathrm{~m}$. The roll circumferential speed is $0.33 \mathrm{mps}$. Two corundum abrasive papers with different granularity marked as P 200 and P 800 were used. Surface exposed to abrasive wear was functional roll surface - cover cladding layer (Viňáš 2003). The face of the sample was active friction area. After abrasive wear test, weight loss of particular tested materials was determined, (figure 11).

Significant marks after action of abrasive grains were observed on the contact surface of samples. However, after abrasive wear test a break of claddings integrity by scaling or disjointing the structure components from cover layer matrix did not occur. The results show that the largest abrasive effect on the sample with claddings had corundum abrasive cloth P 200. The lowest abrasive effect was observed on samples labelled as E processed by corundum abrasive cloth $\mathrm{P}$ 800. The measured values of weight losses are consistent with the hardness of the contact surfaces of samples exposed to abrasive wear. Measured hardness of samples W, in the contact areas, was 400-420 HV30 and the hardness of samples E was 615-650 HV30. 


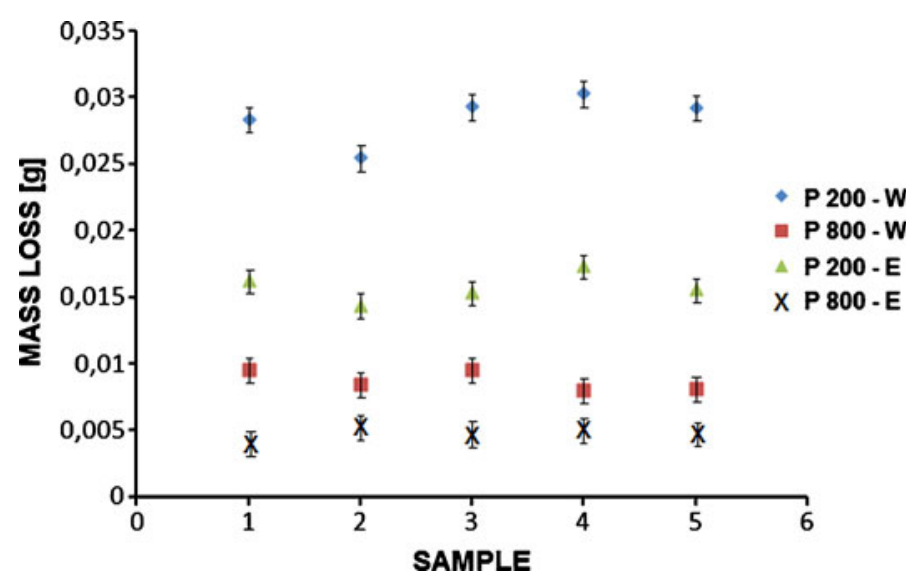

Figure 11. The measured values of weight losses ( $\mathrm{W}$ - sample of renovated roller with cladding layers, E - reference material - new previously unused hardened roller).

\section{Conclusions}

Implementation of renovation process of working surfaces on continual steel casting rolls is the aim of continuous research and development. Requirements for functional surfaces resistance lead to search for a combination of filling materials which allow cost reduction for further technological operations associated with welding or additional processing technologies (thermal regime, etc.) or change the conventional welding methods. One of the prospective savings opportunities and trend in the process of renovating the functional areas of continuous casting rolls is the possibility of restoring worn surfaces using FCAW method. Cladding metal has to contain at least $12 \mathrm{wt} . \% \mathrm{Cr}$ due to passivation of metal corrosion. Carbon content in the cladding should not exceed 0.15 wt. $\%$ to avoid creation of $\mathrm{Cr}_{23} \mathrm{C}_{6}$ at grain boundaries. Creation of $\mathrm{Cr}_{23} \mathrm{C}_{6}$ at grain boundaries lead to reduction of $\mathrm{Cr}$ content in the matrix and increase of martensite susceptibility to cracks formation. Additional material should contain $\mathrm{Nb}$ or $\mathrm{V}$ due to the structure stabilization, but due to increasing resistance to thermal fatigue and creep, it is appropriate if the cladding metal contains nitrogen from 0.10 to 0.20 wt.\%. Nitrogen leads to $\mathrm{CrN}$ and $\mathrm{Cr}_{2} \mathrm{~N}$ formation, which increases the hardness already at low carbon content (Čomaj \& Šef̌ć́k 1999). Nitrides freeze dislocations, grain growth and formation of $\mathrm{Cr}_{23} \mathrm{C}_{6}$. Ms temperature decreases, which results in a fine grained martensitic structure of cladding with fine $\mathrm{Cr}$ nitrides inside the grains.

Based on experimental works done, hardness values correspond to the chemical composition of the investigated materials. The highest average hardness was measured in the cover layer, $1 \mathrm{~mm}$ from the surface, $420 \mathrm{HV} 30$.

Metallographic analysis identified structure of the base material and particular cladding layers. The base material is of martensite-ferrite structure. During the welding process, only a minimum mixing occurs between base material and interlayer. HAZ is relatively narrow. During welding of martensitic materials with high $\mathrm{Cr}$ content, influence of heat introduced by welding leads to the growth of martensitic grains and to segregation of $\mathrm{MC}$ carbides, $\mathrm{Cr}_{23} \mathrm{C}_{6}$ at the grain boundaries, which increases the susceptibility of material to formation of undercladding or annealing cracks. Therefore, in cladding process, it is necessary to pay attention especially to HAZ. The microstructure of the interlayer and cover layers is martensite-ferrite. There were dispersed MC carbides, $\mathrm{M}_{7} \mathrm{C}_{3}$ and $\mathrm{Cr}_{23} \mathrm{C}_{6}$ observed in the interlayer. Also in the cover layer $\mathrm{MC}$ carbides, 
$\mathrm{M}_{7} \mathrm{C}_{3}$ in a significantly lower volume, and $\mathrm{CrN}$ and $\mathrm{Cr}_{2} \mathrm{~N}$ were observed. Dispersion strengthening by metal nitrides and carbides is the way how to increase the resistance of claddings and weld deposits against wear and extend the lifespan of the rollers in metallurgical operations.

\section{Acknowledgement}

This study was supported by the Scientific Agency of Slovak Republic VEGA (project no. 1/0824/12).

\section{References}

Bhattacharya A K and Sambasivam D 2009 Optimization of oscillation parameters in continuous casting process of steel manufacturing: Genetic algorithms versus differential evolution. Evolutionary Computation, W P Santos (ed.) Vienna, Austria: InTech, 572

Blaškovitš P and Čomaj M 2006 Renovation by cladding and thermal spraying (in Slovak), Bratislava: STU Bratisava

Blaškovitš P, Grinberg N A, Suchánek J, Gouveia H, Reis M, Drucová J, Sukubová I, Farkas T and Kasala M 2001 New hardfacing materials for abrasive and erosive conditions. Proc. IIW, Ljubljana

Coe F R 1973 Welding Steels Without Hydrogen Cracking, Technical Report. Abington: The Welding Institute

Čomaj M and Šefčík D 1999 Cladding of continuous stell casting rollers. Proc. XXVII National Conference and Discussion forum Welding, 68

Gooch T G 1977 Welding martensitic stainless steels. TWI Res. Bull., 18: 343

Hrivňák I 1972 Influence of globular inclusions of silicate of plastic properties welding metal. Welding (in Slovak) 21: 295

Kasala J, Pernis R and Mäsiar H 2009 An Application of Robust Parameter Design using Taguchi Method, 2009. Proc. 9th International Foundrymen Conference: Innovative Materials and Advanced Concepts of Metal Casting Production, Zagreb, 6

Kasala J, Mäsiar H and Pernis I 2010 Investigation of selected thermo-physical Properties in the Co-based superalloy: Experiment and Application Study. Arch. Foundry Eng. 10: 203

Mazumdar S and Ray S K 2001 Solidification control in continuous casting of steel. Sädhanā 26(1,2): 179-198

Nakamura H, Naiki T and Okabayashi H 1969 Stress relief cracking in the HAZ. Technical Report IIW-IX648-69. Doc. IIW-II-612-69

Slavkovský F 1987 Renovation of devices for continuous stell casting. Proc. New Directions for Development Processes of Engineering Technology, 101

Šún R 2007 New technological progresses of continual casting rollers renovation. Diploma thesis, Technical University of Košice

Viňáš J 2003 The study of welds -on surfaces making for the purpose of increasing product lifespan, Ph.D. thesis, Technical University of Košice

Viňáš J and Kaščák L' 2008 Possibilities of using welding-on technologies in crane Wheel renovation. Bull. Mater. Sci. 31: 125

Viňáš J and Kačšák L' 2008 Revitalization of crane wheel using cladding technology. Zavarivanje $i$ zavarene konstrukcije 53(1): 3-16

VUZ-PI 2011a Welding Research Institute - Industrial institute of SR. Catalogue of products: Welding wires 2011 http://www.vuz.sk/en/home/Production/Welding-consumables/Tubular-coredwires-and-rods

VUZ-PI 2011b Welding Research Institute - Industrial institute of SR. Catalogue of products: Welding wires 2011 http://www.vuz.sk/en/home/Production/Welding-consumables/Fluxes-for-weldingand-surfacing 
Zeke J and Jánošiová J 1975 Coefficients of Cr oxidation as metallurgical characteristics of welding fluxes. Welding (in Slovak) 24: 193

Zeke J and Mikula K 1973 Mathematical model of expression manganese reaction during submerged arc welding. Research report, VUZ, Bratislava 